\title{
Efektivitas Ekstrak Jambu Biji Merah (Psidium guajava L.) sebagai Antioksidan terhadap Laju Kemunduran Beberapa Varietas Benih Kedelai (Glycine max (L.) Merril.)
}

\author{
Effectivity of Guava Extract (Psidium guajava L.) as an Antioxidant against Seed \\ Deterioration of Soybean Seed (Glycine max (L.) Merril.) Varieties
}

\author{
Dewi Muetia Tasfa ${ }^{1}$, Syamsuddin $^{1}$, Halimursyadah ${ }^{1}$ \\ ${ }^{1}$ Program Studi Agroteknologi, Fakultas Pertanian, Universitas Syiah Kuala
}

\begin{abstract}
Kedelai merupakan salah satu komoditas tanaman pangan terpenting ketiga setelah tanaman pangan padi dan jagung. Konsumsi kedelai semakin meningkat seiring dengan bertambahnya jumlah penduduk sehingga keberadaannya menjadi salah satu faktor terpenting dalam industri pangan dan pakan. Salah satu faktor pembatas produksi kedelai di daerah tropis adalah cepatnya kemunduran benih selama penyimpanan sehingga mengurangi penyediaan benih berkualitas tinggi. Benih kedelai termasuk benih ortodok yang cepat mengalami kemunduran terutama jika kondisi lingkungan simpan kurang menguntungkan (sub optimum). Beberapa hasil penelitian menyatakan bahwa pemberian senyawa antioksidan pada benih dapat meningkatkan viabilitas dan vigor benih melalui metode priming, yaitu metode inkubasi benih dengan menggunakan larutan tertentu. Antioksidan adalah substansi yang berperan untuk menetralisir radikal bebas dan mencegah kerusakan yang ditimbulkan oleh radikal bebas terhadap sel. Ekstrak jambu biji merah diketahui memiliki kandungan antioksidan yang tinggi yang berperan menetralisir kemunduran pada benih yang disebabkan oleh radikal bebas. Penelitian ini menggunakan Rancangan Acak Lengkap pola faktorial 3 x 4 dengan 3 ulangan. Hasil penelitian menunjukkan varietas Dering merupakan varietas terbaik pada tolok ukur viabilitas dan vigor benih dan mampu mempertahankan viabilitasnya sebesar 70,27\% yang berbeda nyata dengan varietas Detam 1 dan Mutiara 3. Ekstrak jambu biji merah terbaik dijumpai pada konsentrasi taraf 50\% dan mampu mempertahankan viabilitas dan vigor benih sebesar $67,79 \%$ yang berbeda nyata dengan kontrol dan berbeda tidak nyata dengan konsentrasi $0 \%, 25 \%$ dan $75 \%$. Terdapat interaksi antara varietas dan konsentrasi ekstrak jambu biji merah yaitu pada varietas Dering dengan konsentrasi ekstrak jambu biji merah $75 \%$ pada tolok ukur potensi tumbuh maksimum.
\end{abstract}

Kata kunci : Kedelai, ekstrak jambu biji merah, antioksidan, kemunduran benih

\begin{abstract}
Soybean (Glycine max (L.) Merril.) is one of the most important food crop commodity after rice and corn. Soybean consumption has increased along with the population increase, that's existence became one of the most important factors in the food and feed industry. One of the limited factors the production of soybean in the tropics is the accelerating pace of decline of seeds during storage, it's reduce the provision of highquality seed. Soybean seeds including seed of a rapid decline orthodoxy especially if environmental conditions save less profitable (sub-optimum). Some of the results study stated that the granting of antioxidant compounds on seed viability and vigor can increase the seed through the priming method, the method of incubation seed with the use of a particular solution. An antioxidant is a substance that acts to neutralize free radicals and prevent damage caused by free radical against cells. Guava extract known have a high content of antioxidants which play a role in neutralizing the decline in seed caused by free radicals. This study used a Randomized Complete design of factorial pattern $3 \times 4$ with 3 replicates. The result showed Dering is the best varieties on benchmark of seed viabilitty and vigor and able to maintain seed viability of 70,27\% real different with varieties of Detam 1 and Mutiara 3 Best concentration guava extract found at concentration level $50 \%$ and was able to maintain seed viability and vigor of $67.79 \%$ real different with controls and unreal with concentrations level $0 \%, 25 \%$ and $75 \%$. There is an interaction between varieties and guava extract concentration in Dering varieties with guava extract concentration level $75 \%$ on the growing potential of the maximum benchmarks.
\end{abstract}

Keywords: soybean, guava extract, antioxidant, seed deterioration 


\section{PENDAHULUAN}

Kedelai (Glycine $\max ($ L.) Merril.) merupakan salah satu komoditas tanaman pangan terpenting ketiga setelah tanaman pangan padi dan jagung sehingga ketersediaan kedelai menjadi salah satu faktor terpenting dalam bidang industri pangan dan pakan (Marwoto et al., 2005). Konsumsi kedelai semakin meningkat seiring dengan peningkatan jumlah penduduk. Kebutuhan kedelai di Indonesia sekitar 2,2 juta ton sedangkan produksi kedelai dalam negeri baru bisa memenuhi sekitar 40\% dan sisanya impor (Balitkabi, 2016).

Salah satu faktor pembatas produksi kedelai di daerah tropis adalah cepatnya kemunduran benih selama penyimpanan hingga mengurangi penyediaan benih berkualitas tinggi. Hal ini disebabkan karena benih kedelai merupakan salah satu dari kelompok benih yang memiliki kadar lemak tinggi. Benih berkadar lemak tinggi selama penyimpanan akan mempercepat terjadinya proses perombakan lemak, dari asam lemak jenuh menjadi asam lemak tidak jenuh atau yang dikenal dengan proses autooksidasi. Tatipata et al. (2004) mengemukakan bahwa proses autooksidasi tersebut memutuskan ikatan rangkap dari asam lemak tak jenuh sehingga menghasilkan radikal-radikal bebas yang berbahaya bagi protein, enzim, kromosom, dan senyawa biologis lainnya dalam sel.

Salah satu cara untuk menghambat proses kemunduran benih karena autooksidasi dapat dilakukan dengan penggunaan antioksidan pada benih. Kandungan vitamin $\mathrm{C}$ dan betakaroten dalam buah jambu biji merah (Psidium guajava L.) diketahui berkhasiat sebagai antioksidan dan dapat meningkatkan daya tahan tubuh, selain itu buah jambu biji juga memiliki serat yang yang tinggi yang larut dalam air terutama pada bagian kulitnya sehingga dapat berperan dalam menghambat kenaikan kadar lipid (Riana, 2000).

Perlakuan pra tanam dengan asam askorbat dan pyridoxine terhadap benih Helianthus annus L., dan Brassica napus L., mampu meningkatkan daya berkecambah benih, mencegah kerusakan protein dan peroksidasi lemak (Dolatabadian dan Modarres Sanavy, 2008). Hasil penelitian Halimursyadah dan Endang (2008) juga mengemukakan bahwa pemberian asam askorbat 300 ppm dan sari buah merah 1\% pada benih kapas (Gossypium hirsutum L.) tidak menunjukkan perbedaan yang nyata, namun asam askorbat cenderung mampu meningkatkan nilai DB, KCT relatif dan IV. Pemberian senyawa antioksidan pada benih dapat dilakukan dengan metode priming. Metode priming merupakan metode inkubasi benih dengan menggunakan larutan tertentu. Salah satu faktor penentu keberhasilan priming selain jenis larutan osmotikum yang digunakan adalah lama waktu yang diperlukan pada proses inkubasi (Liming et al., 1992).

\section{METODE PENELITIAN}

Penelitian ini dilaksanakan di Laboratorium Ilmu dan Teknologi Benih Program Studi Agroteknologi Fakultas Pertanian, Universitas Syiah Kuala

\section{MATERI DAN METODE}

Benih kedelai Dering, Detam 1, dan Mutiara 3 yang diperoleh dari Balitkabi dan BATAN, ekstrak jambu biji merah, aquades, aerator, kertas buram, plastik. 


\section{Metode Penelitian}

\section{Persiapan Benih}

Benih kedelai yang digunakan adalah benih kedelai varietas Dering, Detam 1 dan Mutiara 3. Benih kedelai diperoleh dari Balai Penelitian Tanaman Kacang-kacangan dan Umbi-umbian (Balitkabi) Malang dan Badan Tenaga Nuklir Nasional (Batan) merupakan benih bersertifikat dan benih masih bermutu tinggi dengan viabilitas benih $95 \%$. Benih yang digunakan sebanyak 25 benih untuk setiap ulangannya. Kebutuhan benih dalam penelitian ini adalah 1200 benih.

\section{Ekstraksi Jambu Biji Merah}

Antioksidan yang digunakan adalah ekstrak dari jambu biji merah. Buah jambu biji merah yang digunakan merupakan buah yang sudah masak fisiologis atau ditunjukkan oleh warna kulitnya yang sudah berwarna kuning. Buah jambu biji terlebih dahulu dicuci dengan air bersih, dipotong dengan ukuran kecil dengan tanpa dibuang kulit dan bijinya kemudian dihaluskan dengan menggunakan blender tanpa dicampur air. Jambu biji merah yang sudah halus kemudian disaring menggunakan kain kasa sehingga didapatkan ekstrak jambu biji merah yang murni. Kebutuhan buah jambu biji merah yang dibutuhkan dalam penelitian ini sebanyak $6 \mathrm{~kg}$.

\section{Perlakuan Benih dengan Ekstrak Jambu Biji Merah}

Benih kedelai diberi perlakuan antioksidan ekstrak jambu biji merah melalui metode priming dengan masing-masing konsentrasi $(0 \%, 25 \%, 50 \%$, dan 75\%). Kebutuhan ekstrak jambu biji merah pada masing-masing konsentrasi 25\% (62,5 ml), 50\% (125 ml) dan 75\% $(187,5 \mathrm{ml})$ ditambahkan aquades hingga mencapai $250 \mathrm{ml}$, kemudian benih dimasukkan ke dalam botol air mineral yang sudah berisi ekstrak jambu biji merah dengan menggunakan metode priming selama 6 jam pada suhu ruangan $\left(28^{\circ} \mathrm{C}\right)$. Ketersediaan oksigen selama proses priming dijaga dengan menggunakan aerator. Setelah proses priming selesai dilakukan, benih dicuci hingga bersih dan kadar air benih diturunkan seperti kadar air awal dengan cara dikering anginkan pada suhu ruangan selama 2 x 24 jam.

\section{Penentuan Daya Simpan Benih}

Penentuan daya simpan benih mengguanakan metode Delouche yaitu pengusangan cepat secara fisik (acceleretaed aging). Pengusangan cepat secara fisik dimaksudkan untuk menguji daya simpan benih kedelai hasil perlakuan benih menggunakan antioksidan secara artifisial. Metode tersebut dilakukan untuk mensimulasi periode simpan benih kedelai yang terjadi secara alami (Delouche, 1971) yaitu dengan cara menggunakan suhu $40{ }^{\circ} \mathrm{C}$ dan kelembaban $100 \%$.

\section{Penanaman Benih}

Penanaman benih kedelai dilakukan setelah benih diberi perlakuan priming dan pengusangan cepat secara fisik. Pengujian viabilitas dan vigor kekuatan tumbuh benih menggunakan metode Uji Kertas Digulung didirikan dalam plastik (UKDdp). Sebanyak 25 butir benih dikecambahakan untuk setiap satuan percobaan. Untuk menjaga agar kondisi perkecambahan tetap optimum, benih yang sudah ditanam ditempatkan di dalam germinator. 


\section{Pegujian Daya Hantar Listrik (DHL) Benih}

Pengujian DHL benih dilakukan pada saat benih telah dilakukan pengusangan cepat secara fisik. Benih diambil 5 butir dari setiap perlakuan kemudian direndam dengan menggunakan aquades selama 24 jam. Setelah direndam selama 24 jam, benih dikeluarkan dari dalam botol kemudian diukur larutannya dengan alat conductivity meter yang bertujuan untuk mengetahui kebocoran membran sel yang terjadi di dalam benih.

\section{Analisis Statistik}

Penelitian ini menggunakan Rancangan Acak Lengkap (RAL) pola faktorial 3x4 dengan dua faktor yang diteliti. Faktor pertama varietas (V) yang terdiri dari 3 taraf yaitu: $V_{1}$ (Dering), $\mathrm{V}_{2}$ (Detam 1) dan $\mathrm{V}_{3}$ (Mutiara 3). Faktor kedua konsentrasi ekstrak jambu biji merah (K) yang terdiri dari 4 taraf yaitu: $\mathrm{K}_{0}$ (Kontrol), $\mathrm{K}_{1}(25 \%), \mathrm{K}_{2}(50 \%)$ dan $\mathrm{K}_{3}(75 \%)$. Terdapat 12 jumlah kombinasi perlakuan, masing-masing kombinasi diulang sebanyak 3 kali, sehingga didapat 36 satuan percobaan.

\section{HASIL DAN PEMBAHASAN}

\section{Perlakuan Varietas terhadap Laju Kemunduran Beberapa Varietas Benih Kedelai}

Hasil analisis ragam (Uji F) menunjukkan bahwa perlakuan varietas berpengaruh sangat nyata terhadap potensi tumbuh maksimum, daya berkecambah, indeks vigor, kecepatan tumbuh relatif, keserempakan tumbuh dan $\mathrm{T}_{50}$, berbeda nyata terhadap tolok ukur daya hantar listrik (DHL) dan berbeda tidak nyata terhadap bobot kering biomassa kecambah normal.

Tabel 1. Rata-rata nilai masing-masing tolok ukur yang diamati pada beberapa varietas benih kedelai terhadap laju kemunduran beberapa varietas benih kedelai

\begin{tabular}{ccccccccc}
\hline & \multicolumn{7}{c}{ Tolok ukur yang diamati } \\
\cline { 2 - 9 } $\mathrm{V}$ & $\begin{array}{c}\mathrm{PTM} \\
(\%)\end{array}$ & $\begin{array}{c}\mathrm{DB} \\
(\%)\end{array}$ & $\begin{array}{c}\mathrm{IV} \\
(\%)\end{array}$ & $\begin{array}{c}\mathrm{K}_{\mathrm{CT}}-\mathrm{R} \\
(\% / \mathrm{etmal})\end{array}$ & $\begin{array}{c}\mathrm{K}_{\mathrm{ST}} \\
(\%)\end{array}$ & $\begin{array}{c}\mathrm{T}_{50} \\
(\text { hari })\end{array}$ & $\begin{array}{c}\text { BKBKN } \\
(\mathrm{g})\end{array}$ & $\begin{array}{c}\mathrm{DHL} \\
\left(\mu \mathrm{Scm}^{-1}\right. \\
\mathrm{g}^{-1)}\end{array}$ \\
\hline $\mathrm{V}_{1}$ & $70,27 \mathrm{~b}$ & $61,26 \mathrm{c}$ & $55,35 \mathrm{c}$ & $59,20 \mathrm{c}$ & $58,57 \mathrm{c}$ & $0,99 \mathrm{a}$ & 1,49 & $0,88 \mathrm{a}$ \\
$\mathrm{V}_{2}$ & $59,53 \mathrm{a}$ & $54,06 \mathrm{~b}$ & $48,60 \mathrm{~b}$ & $52,86 \mathrm{~b}$ & $51,99 \mathrm{~b}$ & $1,35 \mathrm{~b}$ & 1,47 & $0,94 \mathrm{a}$ \\
$\mathrm{V}_{3}$ & $56,60 \mathrm{a}$ & $45,65 \mathrm{a}$ & $41,12 \mathrm{a}$ & $44,71 \mathrm{a}$ & $44,26 \mathrm{a}$ & $1,07 \mathrm{a}$ & 1,46 & $1,14 \mathrm{~b}$ \\
\hline $\mathrm{BNJ}_{0,05}$ & 6,21 & 6,22 & 6,25 & 6,19 & 6,32 & 0,095 & - & 0,225 \\
\hline
\end{tabular}

Keterangan: Angka yang diikuti oleh huruf yang sama pada kolom yang sama berbeda tidak nyata pada taraf 5\% (Uji BNJ ${ }_{0,05}$ ); $\mathrm{V}_{1}$ : Dering; $\mathrm{V}_{2}$ : Detam 1; $\mathrm{V}_{3}$ : Mutiara 3; PTM: potensi tumbuh maksimum; DB: daya berkecambah; IV: indeks vigor; $\mathrm{K}_{\mathrm{CT}}-\mathrm{R}$ : kecepatan tumbuh relatif; $\mathrm{K}_{\mathrm{ST}}$ : keserempakan tumbuh; $\mathrm{T}_{50}$ : waktu yang dibutuhkan untuk mencapai $50 \%$ perkecambahan total; BKBKN: berat kering biomassa kecambah normal; DHL: daya hantar listrik

Efektivitas Ekstrak Jambu Biji Merah (Psidium guajava L.) sebagai Antioksidan terhadap Laju Kemunduran Beberapa Varietas Benih Kedelai (Glycine max (L.) Merril.) (Dewi Muetia Tasfa, Syamsuddin, Halimursyadah) Jurnal Ilmiah Mahasiswa Pertanian Unsyiah, Vol. 1, No. 1, November 2016: 239-250 
Tabel 1 menunjukkan bahwa rata-rata nilai potensi tumbuh maksimum tertinggi diperoleh pada varietas Dering yaitu $70,27 \%$ yang berbeda nyata dengan varietas Detam 1 yaitu $59,53 \%$ dan varietas Mutiara 3 yaitu 56,60\%. Hal yang sama juga didapatkan pada nilai daya berkecambah, indeks vigor, kecepatan tumbuh relatif dan keserempakan tumbuh. Nilai tertinggi diperoleh pada varietas Dering yang berbeda nyata dengan nilai dari varietas Detam 1 dan varietas Mutiara 3. Pada tolok ukur DHL menunjukkan bahwa perbedaan varietas yang dicobakan menyebabkan terjadinya perbedaan nilai DHL. Di antara tiga varietas yang dicobakan, varietas Mutiara 3 berbeda nyata dengan varietas Dering dan varietas Detam 1. Nilai DHL pada varietas Mutiara 3 yaitu $1,14 \mu \mathrm{Scm}^{-1} \mathrm{~g}^{-1}$ yang berbeda nyata dengan varietas Dering yaitu $0,88 \mu \mathrm{Scm}^{-1} \mathrm{~g}^{-1}$ dan varietas Detam 1 yaitu $0,94 \mu \mathrm{Scm}^{-1} \mathrm{~g}^{-1}$. Hasil tersebut bermakna bahwa tingkat kebocoran benih varietas Dering dan Detam 1 lebih rendah dibandingkan dengan varietas Mutiara 3, dengan demikian laju kemunduran benih juga lebih rendah sehingga benih masih memiliki nilai viabilitas yang tinggi. Pengaruh varietas terhadap peningkatan daya hantar listrik juga memberikan respon yang berbeda.

Perbedaan viabilitas benih yang ditunjukkan pada masing-masing varietas kedelai disebabkan karena adanya perbedaan sifat genetik dari masing-masing varietas yang dicobakan. Sadjad (1993) menyatakan bahwa perbedaan daya tumbuh antar varietas ditentukan oleh faktor genetiknya. Varietas tanaman yang berbeda akan menunjukkan pertumbuhan dan hasil yang berbeda meskipun tanaman tersebut ditanam pada kondisi lingkungan yang sama (Marliah et al., 2012).

Berdasarkan hasil penelitian pada tolok ukur DHL, dari ketiga benih yang dicobakan benih yang mengalami kebocoran membran terkecil dijumpai pada benih varietas Dering yaitu $0,88 \mu \mathrm{Scm}^{-1} \mathrm{~g}^{-1}$ yang berarti bahwa benih masih memiliki nilai viabilitas yang tinggi. Apabila kebocoran membran menunjukkan nilai yang tinggi, hal tersebut dapat mengakibatkan rendahnya energi yang diterima oleh embrio (Anggraeni dan Faiza, 2013). Kebocoran membran yang terjadi pada benih mengakibatkan terjadinya kemunduran benih yang akan mempengaruhi embrio dan kotiledon yang sebagian besar terdiri atas karbohidrat, protein dan lemak yang berfungsi untuk perkecambahan benih (Purwanti, 2004).

\section{Perlakuan Konsentrasi Ekstrak Jambu Biji Merah terhadap Laju Kemunduran Beberapa Varietas Benih Kedelai}

Hasil analisis ragam (Uji F) menunjukkan bahwa perlakuan konsentrasi berpengaruh sangat nyata terhadap tolok ukur potensi tumbuh maksimum. Sedangkan tolok ukur daya berkecambah, indeks vigor, kecepatan tumbuh relatif dan keserempakan tumbuh, waktu yang dibutuhkan untuk mencapai 50\% perkecambahan total dan bobot kering biomassa kecambah normal menunjukkan pengaruh yang nyata.

Rata-rata nilai potensi tumbuh maksimum tertinggi diperoleh pada perlakuan konsentrasi ekstrak jambu biji merah pada taraf konsentrasi $50 \%$ yaitu $67,79 \%$ yang berbeda nyata dengan taraf konsentrasi $0 \%$ yaitu $59,43 \%$, namun berbeda tidak nyata dengan taraf konsentrasi $25 \%$ dan $75 \%$ yaitu $60,28 \%$ dan $61,01 \%$. Rata-rata nilai daya berkecambah tertinggi diperoleh pada taraf konsentrasi $50 \%$ yaitu $61,97 \%$ yang berbeda nyata pada taraf konsentrasi $0 \%, 25 \%$ dan $75 \%$.

Rata-rata nilai indeks vigor tertinggi diperoleh pada taraf konsentrasi $50 \%$ yaitu sebesar 55,87\% yang berbeda nyata pada taraf konsentrasi 0\%, 25\% dan $75 \%$ secara

Efektivitas Ekstrak Jambu Biji Merah (Psidium guajava L.) sebagai Antioksidan terhadap Laju Kemunduran Beberapa Varietas Benih Kedelai (Glycine max (L.) Merril.) (Dewi Muetia Tasfa, Syamsuddin, Halimursyadah) Jurnal Ilmiah Mahasiswa Pertanian Unsyiah, Vol. 1, No. 1, November 2016: 239-250 
berurutan yaitu 43,04\%, 47,69\% dan 46,82\%. Rata-rata nilai kecepatan tumbuh relatif pada taraf konsentrasi $50 \%$ berbeda nyata sebesar $60,55 \%$ dan berbeda tidak nyata pada taraf konsentrasi $0 \%$ sebesar $46,93 \%, 25 \%$ dan $75 \%$ yaitu $51,98 \%$ dan $49,67 \%$.

Tabel 2. Rata-rata nilai masing-masing tolok ukur yang diamati pada beberapa taraf konsentrasi ekstrak jambu biji merah terhadap laju kemunduran beberapa varietas benih kedelai

\begin{tabular}{ccccccccc}
\hline & \multicolumn{8}{c}{ Tolok ukur yang diamati } \\
\cline { 2 - 9 } $\begin{array}{c}\mathrm{K} \\
(\%)\end{array}$ & $\begin{array}{c}\text { PTM } \\
(\%)\end{array}$ & $\begin{array}{c}\mathrm{DB} \\
(\%)\end{array}$ & $\begin{array}{c}\mathrm{IV} \\
(\%)\end{array}$ & $\begin{array}{c}\mathrm{K}_{\mathrm{CT}-\mathrm{R}} \\
(\% / \text { etmal })\end{array}$ & $\begin{array}{c}\mathrm{K}_{\mathrm{ST}} \\
(\%)\end{array}$ & $\begin{array}{c}\mathrm{T}_{50} \\
(\text { hari })\end{array}$ & $\begin{array}{c}\text { BKBKN } \\
(\mathrm{g})\end{array}$ & $\begin{array}{c}(\mu \mathrm{S} \\
\mathrm{cm}^{-1} \\
\left.\mathrm{~g}^{-1}\right)\end{array}$ \\
\hline $\mathrm{K}_{0}$ & $59,43 \mathrm{a}$ & $48,27 \mathrm{a}$ & $43,04 \mathrm{a}$ & $46,93 \mathrm{a}$ & $45,91 \mathrm{a}$ & $1,03 \mathrm{a}$ & $1,42 \mathrm{a}$ & 1,12 \\
$\mathrm{~K}_{1}$ & $60,28 \mathrm{ab}$ & $53,12 \mathrm{a}$ & $47,69 \mathrm{a}$ & $51,98 \mathrm{a}$ & $51,48 \mathrm{ab}$ & $1,13 \mathrm{ab}$ & $1,48 \mathrm{a}$ & 1,00 \\
$\mathrm{~K}_{2}$ & $67,79 \mathrm{~b}$ & $61,97 \mathrm{~b}$ & $55,87 \mathrm{~b}$ & $60,55 \mathrm{~b}$ & $59,37 \mathrm{~b}$ & $1,18 \mathrm{~b}$ & $1,58 \mathrm{~b}$ & 0,86 \\
$\mathrm{~K}_{3}$ & $61,01 \mathrm{ab}$ & $51,27 \mathrm{a}$ & $46,82 \mathrm{a}$ & $49,56 \mathrm{a}$ & $49,67 \mathrm{a}$ & $1,21 \mathrm{~b}$ & $1,43 \mathrm{a}$ & 0,96 \\
\hline $\mathrm{BNJ}$ & 7,92 & 7,94 & 7,97 & 7,90 & 8,06 & 0,120 & 0,086 & -
\end{tabular}

0,05

Keterangan: Angka yang diikuti oleh huruf yang sama pada kolom yang sama berbeda tidak nyata pada taraf $5 \%$ (Uji BNJ $\left.{ }_{0,05}\right) ; \mathrm{V}_{1}$ : Dering; $\mathrm{V}_{2}$ : Detam 1; $\mathrm{V}_{3}$ : Mutiara 3; PTM: potensi tumbuh maksimum; DB: daya berkecambah; IV: indeks vigor; $\mathrm{K}_{\mathrm{CT}}-\mathrm{R}$ : kecepatan tumbuh relatif; $\mathrm{K}_{\mathrm{ST}}$ : keserempakan tumbuh; $\mathrm{T}_{50}$ : waktu yang dibutuhkan untuk mencapai $50 \%$ perkecambahan total; BKBKN: berat kering biomassa kecambah normal; DHL: daya hantar listrik

Rata-rata keserempakan tumbuh tertinggi diperoleh pada taraf konsentrasi $50 \%$ yaitu sebesar 59,37\% yang berbeda nyata dengan taraf konsentrasi $0 \%$ yaitu $45,91 \%$ dan $75 \%$ sebesar 49,67\% namun tidak berbeda nyata dengan taraf konsentrasi $25 \%$ sebesar 51,48\%. Berdasarkan tabel tersebut juga dapat disimpulkan bahwa taraf konsentrasi $50 \%$ ekstrak jambu biji merah mampu mempertahankan laju kemunduran benih kedelai setelah mengalami pengusangan dan dapat mempertahankan nilai viabilitas benih.

Hasil penelitian menunjukkan bahwa rata-rata nilai $\mathrm{T}_{50}$ tercepat diperoleh pada taraf konsentrasi $0 \%$ yaitu 1,03 hari yang berbeda nyata dengan taraf konsentrasi $50 \%$ dan $75 \%$ yaitu selama 1,18 hari dan 1,21 hari meskipun berbeda tidak nyata pada taraf konsentrasi $25 \%$ yaitu 1,13 hari. Rata-rata nilai bobot kering biomassa kecambah normal tertinggi diperoleh pada taraf konsentrasi $50 \%$ yaitu 1,58 g yang berbeda nyata dengan taraf konsentrasi $0 \%$, $25 \%$ dan $75 \%$ secara berurutan yaitu 5,76 g, 6,23 g dan 5,82 g. Hal ini disebabkan oleh konsentrasi yang tepat mampu meningkatkan viabilitas benih kedelai dan mampu menekan laju kemunduran benih.

Hasil penelitian juga menunjukkan terdapat hubungan antara tingkat konsentrasi ekstrak jambu biji merah terhadap laju kemunduran benih kedelai. Hubungan dari masing-masing tolok ukur ditunjukkan oleh persamaan regresi linear secara berurutan yaitu potensi tumbuh maksimum $(\mathrm{PTM}) \mathrm{y}=49,027 \mathrm{x}(0,025)+60,291=61,516, \mathrm{R}^{2}=0,1707$; daya berkecambah

Efektivitas Ekstrak Jambu Biji Merah (Psidium guajava L.) sebagai Antioksidan terhadap Laju Kemunduran Beberapa Varietas Benih Kedelai (Glycine max (L.) Merril.) (Dewi Muetia Tasfa, Syamsuddin, Halimursyadah) Jurnal Ilmiah Mahasiswa Pertanian Unsyiah, Vol. 1, No. 1, November 2016: 239-250 
(DB) $\mathrm{y}=71,427 \mathrm{x}(0,025)+50,977=52,76, \mathrm{R}^{2}=0,153$ dan indeks vigor $(\mathrm{IV}) \mathrm{y}=78,076 \mathrm{x}$ $(0,025)+45,427=47,37, R^{2}=0,2179$. Penambahan setiap $25 \%$ ekstrak jambu biji merah terjadi penambahan persentase viabilitas dan vigor benih berdasarkan tolok ukur yang diamati secara berurutan yaitu PTM $(61,516)$, DB $(52,76)$, IV (47,37). Apabila nilai $\mathrm{R}^{2}$ menunjukkan angka yang semakin besar, maka terdapat hubungan yang sangat erat. Artinya, setiap penambahan tingkat konsentrasi ekstrak jambu biji merah dapat menghambat laju kemunduran benih kedelai.

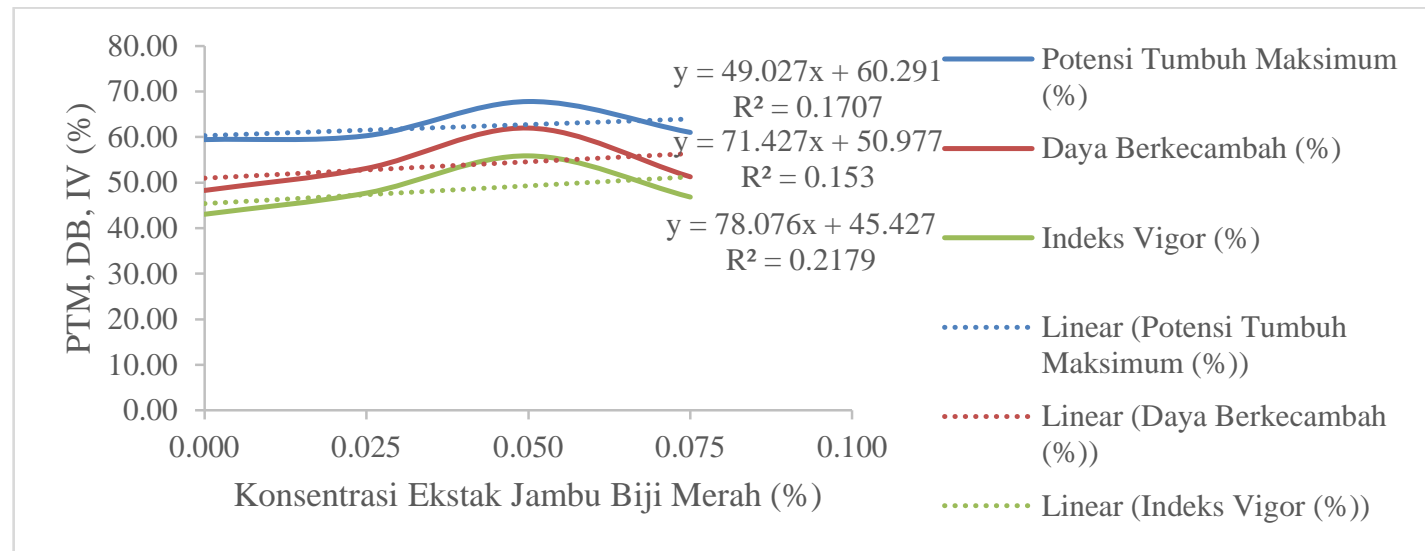

Gambar 1. Hubungan konsentrasi ekstrak jambu biji merah (\%) berdasarkan tolok ukur potensi tumbuh maksimum, daya berkecambah dan indeks vigor beberapa varietas benih kedelai

Berdasarkan tolok ukur kecepatan tumbuh relatif dan keserempakan tumbuh juga menunjukkan adanya hubungan yang sangat erat. Artinya, setiap penambahan konsentrasi ekstrak jambu biji merah sebesar $25 \%$ dapat menghambat laju kemunduran benih kedelai. Hubungan dari masing-masing tolok ukur ditunjukkan oleh persamaan regresi linear secara berurutan yaitu kecepatan tumbuh relatif $\left(\mathrm{K}_{\mathrm{CT}}-\mathrm{R}\right) \mathrm{y}=65,764 \mathrm{x}(0,025)+49,789=51,433, \mathrm{R}^{2}=$ 0,1294 dan keserempakan tumbuh $\left(\mathrm{K}_{\mathrm{ST}}\right) \mathrm{y}=76,764 \mathrm{x}(0,025)+48,278=50,197, \mathrm{R}^{2}=0,1909$.

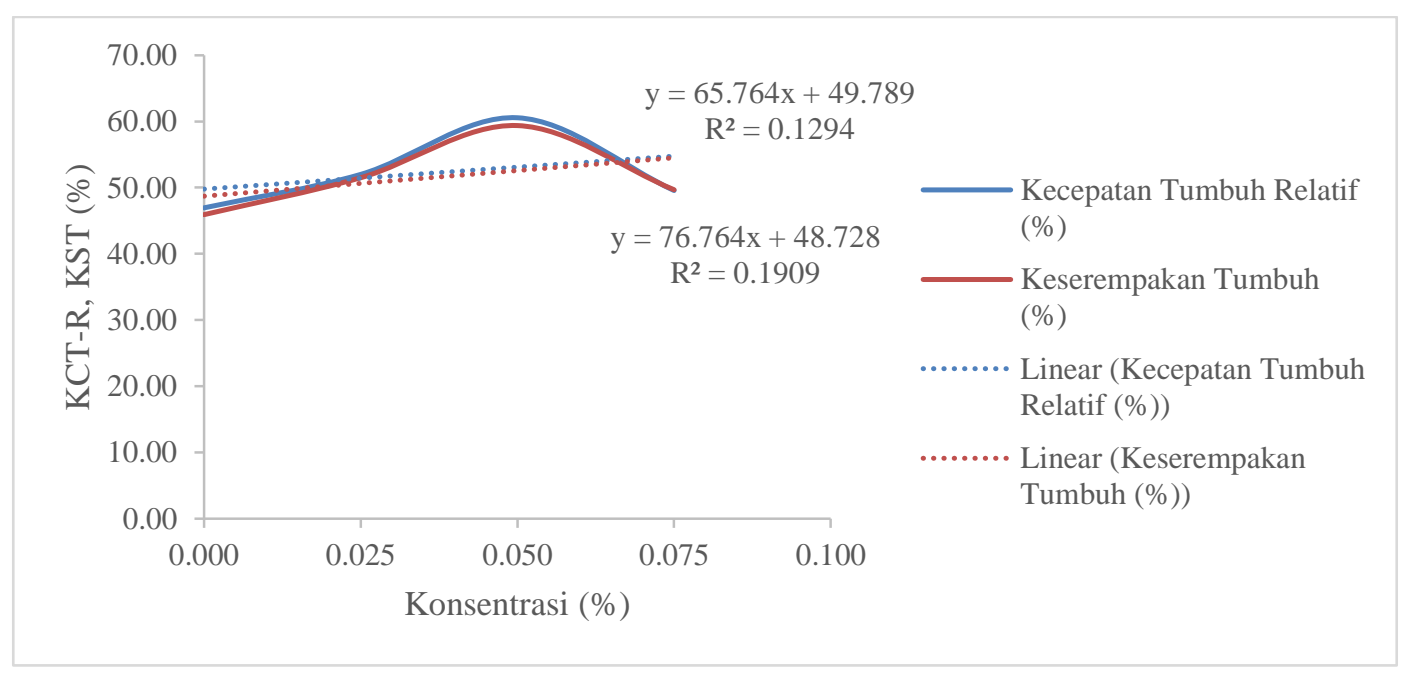

Efektivitas Ekstrak Jambu Biji Merah (Psidium guajava L.) sebagai Antioksidan terhadap Laju Kemunduran Beberapa Varietas Benih Kedelai (Glycine max (L.) Merril.) (Dewi Muetia Tasfa, Syamsuddin, Halimursyadah) Jurnal Ilmiah Mahasiswa Pertanian Unsyiah, Vol. 1, No. 1, November 2016: 239-250 
Gambar 2. Hubungan konsentrasi ekstrak jambu biji merah (\%) berdasarkan tolok ukur potensi tumbuh maksimum, daya berkecambah dan indeks vigor beberapa varietas benih kedelai

Pada tolok ukur $\mathrm{T}_{50}$ menunjukkan bahwa terdapat hubungan antara taraf Pada tolok ukur $\mathrm{T}_{50}$ menunjukkan bahwa terdapat hubungan antara taraf konsentrasi ekstrak jambu biji merah terhadap laju kemunduran benih. Persamaan regresi linear pada tolok ukur ini yaitu $\mathrm{y}=$ $2,305 x(0,025)+1,0502=1,107, R^{2}=0,9313$. Setiap penambahan konsentrasi ekstrak jambu biji merah $25 \%$ terjadi pengurangan waktu sebesar 0,9313 hari.

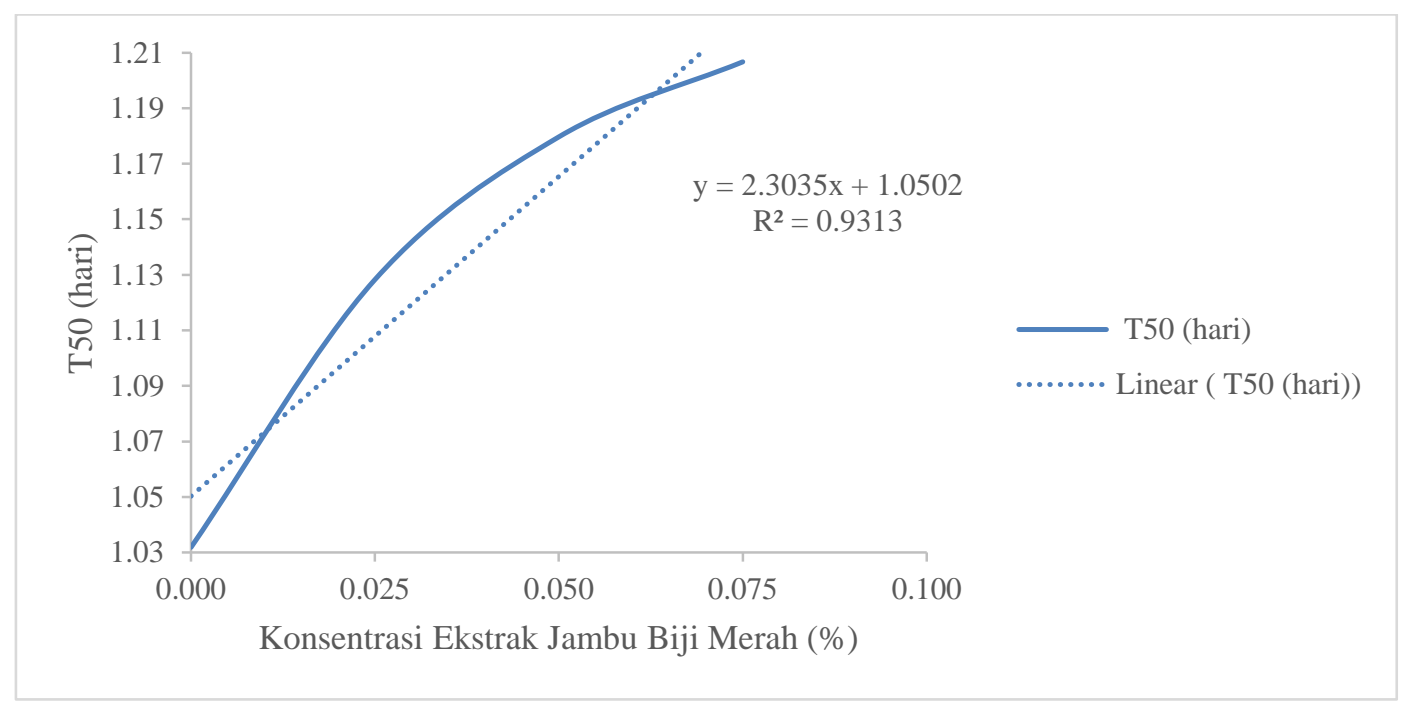

Gambar 3. Hubungan konsentrasi ekstrak jambu biji merah (\%) berdasarkan tolok ukur $\mathrm{T}_{50}$ (hari)

Pada tolok ukur bobot kering biomassa kecambah normal menunjukkan bahwa terdapat hubungan antara taraf konsentrasi ekstrak jambu biji merah terhadap laju kemunduran benih. Persamaan regresi linear pada tolok ukur ini yaitu bobot kering biomassa kecambah normal $(\mathrm{BKBKN}) \mathrm{y}=0,52 \mathrm{x}(0,025)+1,458=1,471$. 


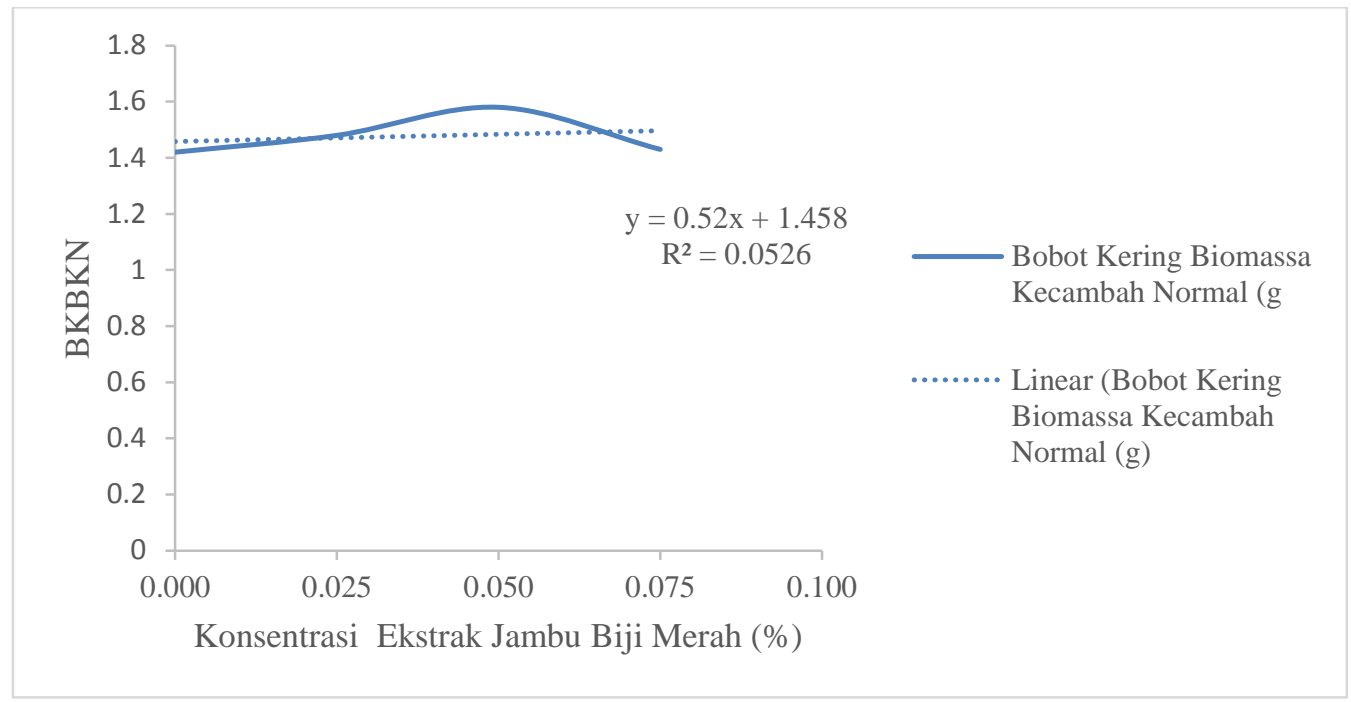

Gambar 4. Hubungan konsentrasi ekstrak jambu biji merah (\%) berdasarkan tolok ukur bobot kering kecambah normal (BKBKN)

Menurut Rini et al. (2005) menyatakan bahwa keberhasilan osmoconditioning atau priming pada benih sangat ditentukan oleh jenis larutan yang digunakan, potensial osmotik, suhu dan lamanya inkubasi serta akan berpengaruh antar spesies dan varietas benih. Untuk menghambat benih berkecambah selama proses priming berlangsung, larutan diberikan $\mathrm{KNO}_{3}$ sebanyak 6,19 g, hal ini sesuai dengan hasil penelitian Rizki (2013) yang menyatakan bahwa tekanan osmosis larutan $\mathrm{KNO}_{3}$ yang efektif dalam priming benih kedelai adalah -6.0 Bar (24,78 $\mathrm{g} \mathrm{L}^{-1}$ air).

Hasil penelitian Junita (2014) juga menunjukkan pemberian senyawa antioksidan curcumin pada benih kedelai melalui metode priming dengan $25 \%$ mampu mempertahankan viabilitas dan vigor benih kedelai. Berdasarkan data pada Tabel 5 menunjukkan bahwa konsentrasi ekstrak jambu biji merah terbaik adalah konsentrasi $50 \%$ yang mampu mempertahankan nilai viabilitas dan vigor benih. Rata-rata nilai viabilitas dan vigor benih berdasarkan masing-masing tolok ukur secara berurutan yaitu potensi tumbuh maksimum (PTM) 67,79\%, daya berkecambah 61,97\% (DB), indeks vigor (IV) 55,87\%, kecepatan tumbuh relatif $\left(\mathrm{K}_{\mathrm{CT}}-\mathrm{R}\right) 60,55 \%$ dan keserempakan tumbuh $\left(\mathrm{K}_{\mathrm{ST}}\right) 59,37 \%$.

Penambahan konsentrasi ekstrak jambu biji merah menjadi $75 \%$ cenderung menurunkan nilai viabilitas dan vigor benih kedelai. Hal ini terjadi karena pemberian antioksidan ekstrak jambu biji merah dengan konsentrasi yang tepat mampu menghambat atau mencegah proses oksidasi lemak atau minyak sehingga mempunyai fungsi sebagai pengawet, selain itu antioksidan juga memiliki peran dalam sistem biologis untuk menangkal radikal bebas (Arief, 2006).

\section{Interaksi antara Perlakuan Varietas dan Konsentrasi Ekstrak Jambu Biji Merah terhadap Laju Kemunduran Beberapa Varietas Benih Kedelai}


Hasil analisis ragam (Uji F) menunjukkan bahwa terdapat interaksi sangat nyata antara varietas dan konsentrasi ekstrak jambu biji merah terhadap tolok ukur potensi tumbuh maksimum.

Tabel 3. Rata-rata nilai interaksi potensi tumbuh maksimum beberapa varietas benih kedelai dengan taraf konsentrasi ekstrak jambu biji merah

\begin{tabular}{ccccc}
\hline \multirow{3}{*}{ Varietas } & \multicolumn{4}{c}{ Tolok ukur yang Diamati } \\
\cline { 2 - 5 } & $\mathrm{K}_{0}$ & $\mathrm{~K}_{1}$ & $\mathrm{~K}_{2}$ & $\mathrm{~K}_{3}$ \\
\cline { 2 - 5 } $\mathrm{V}_{1}$ & $61,80 \mathrm{Aa}$ & $66,89 \mathrm{Aa}$ & $75,55 \mathrm{Aa}$ & $76,83 \mathrm{Ba}$ \\
$\mathrm{V}_{2}$ & $62,51 \mathrm{Aa}$ & $51,57 \mathrm{Aa}$ & $64,73 \mathrm{Aa}$ & $59,29 \mathrm{ABa}$ \\
$\mathrm{V}_{3}$ & $53,98 \mathrm{Aa}$ & $62,39 \mathrm{Aa}$ & $63,09 \mathrm{Aa}$ & $46,92 \mathrm{Aa}$ \\
\hline BNJ & \multicolumn{4}{c}{24,93}
\end{tabular}

Keterangan: Angka yang diikuti oleh huruf yang sama (huruf besar pada kolom yang sama, huruf kecil pada baris yang sama) menunjukkan berbeda tidak nyata pada taraf $5 \%$ (BNJ ${ }_{0,05}$ ); PTM: potensi tumbuh maksimum

Tabel 3 menunjukkan bahwa rata-rata nilai interaksi potensi tumbuh maksimum berdasarkan perlakuan varietas dan konsentrasi berbeda nyata pada varietas Dering pada konsentrasi ekstrak jambu biji merah $75 \%$ sebesar 76,83\% dengan varietas Mutiara 3 pada konsentrasi $75 \%$ sebesar $46,92 \%$ dan berbeda tidak nyata dengan varietas Detam 1 pada konsentrasi $75 \%$ sebesar 59,29\%. Perlakuan ketiga varietas yang dicobakan dengan konsentrasi ekstrak jambu biji merah $0 \%, 25 \%$ dan $50 \%$ berbeda tidak nyata pada setiap penambahan ekstrak jambu biji merah.

Hasil penelitian menunjukkan bahwa terdapat interaksi yang nyata antara varietas dan konsentrasi ekstrak jambu biji merah pada tolok ukur potensi tumbuh maksimum (PTM). Nilai potensi tumbuh maksimum pada varietas Dering cenderung lebih tinggi pada setiap taraf ekstrak jambu biji merah dibandingkan dengan varietas Detam 1 dan Mutiara 3. Viabilitas benih dapat diukur dengan tolok ukur daya berkecambah (germination capacity). Perkecambahan benih adalah muncul dan berkembangnya struktur terpenting dari embrio benih serta kecambah tersebut menunjukkan kemampuan untuk berkembang menjadi tanaman normal pada kondisi lingkungan yang menguntungkan. Viabilitas benih menunjukkan daya hidup benih, aktif secara metabolik dan memiliki enzim yang dapat mengkatalis reaksi metabolik yang diperlukan untuk perkecambahan dan pertumbuhan kecambah (Copeland dan Donald, 2001).

Pemberian senyawa antioksidan yang telah mengalami pengusangan dapat membantu nilai viabilitas benih, karena antoksidan yang diserap oleh benih berperan dalam menghambat terjadinya autooksidasi yang terjadi pada benih sehingga dapat meningkatkan daya berkecambah pada benih. Rachmawati (2010) menyatakan bahwa antioksidan merupakan senyawa yang dapat menetralisir radikal bebas yang dapat merusak sel apabila kekurangan zat antioksidan, merusak membran sel, merubah zat kimia dan dapat merusak protein sehingga menyebabkan cepatnya terjadi proses penuaan. Lumbanraja (2006) menyatakan bahwa pemberian antioksidan asam askorbat dan curcuma pada benih efektif meningkatkan viabilitas dan vigor benih pepaya.

Antioksidan seperti asam askorbat dapat digunakan dalam coating sebagai penangkap radikal bebas dan mencegah kemunduran benih akibat oksidasi lemak. Hasil penelitian 
Yuningsih (2009) menunjukkan bahwa coating benih buncis dengan $350 \mathrm{ppm}$ asam askorbat mampu mempertahankan viabilitasnya hingga 20 minggu pada sistem penyimpanan terbuka dalam kemasan plastik dengan daya berkecambah 96.67\%, lebih tinggi dibandingkan tanpa perlakuan coating yang hanya $91.33 \%$. Hasil penelitian Jannah (2014) juga menunjukkan bahwa masa simpan benih selama 4 minggu dengan menggunakan asam askorbat dari ekstrak buah nanas dapat mempertahankan viabilitas dan vigor benih kedelai.

\section{KESIMPULAN DAN SARAN}

Varietas Dering merupakan varietas benih kedelai terbaik dari dua varietas lainnya yang dicobakan. Hal ini ditunjukkan berdasarkan tolok ukur yang diamati yaitu PTM, DB, IV, $\mathrm{K}_{\mathrm{CT}^{-}}$ $\mathrm{R}, \mathrm{K}_{\mathrm{ST}}, \mathrm{T}_{50}$ dan DHL. Konsentrasi ekstrak jambu biji merah terbaik dijumpai pada taraf konsentrasi 50\%. Ekstrak jambu biji merah pada taraf 50\% mampu menghambat laju kemunduran benih pada beberapa varietas kedelai yang dicobakan. Hal ini ditunjukkan berdasarkan tolok ukur yang diamati yaitu PTM, DB, IV, $\mathrm{K}_{\mathrm{CT}}-\mathrm{R}, \mathrm{K}_{\mathrm{ST}}, \mathrm{T}_{50}$ dan BKBKN. Terdapat interaksi yang berbeda nyata antara perlakuan varietas dengan konsentrasi ekstrak jambu biji merah pada tolok ukur PTM, dijumpai pada varietas Dering dengan taraf konsentrasi $75 \%$.

\section{DAFTAR PUSTAKA}

Angraeni, N.D., dan F.C. Suwarno. 2013. Kemampuan benih kedelai (Glycine max L.) Untuk mempertahankan viabilitasnya setelah didera dengan etanol. Bul. Agrohorti. 1 (4): 3444.

Arief, S. 2006. Radikal bebas. Fakultas Kedokteran UNAIR. Surabaya

Balitkabi, 2016. Balitbangtan Gelar Teknologi Budidaya Kedelai Grobogan 3 Ton per Hektar. http://balitkabi.litbang.pertanian.go.id/ [diakses 27 Januari 2016]

Copeland, L. O., dan M. B. McDonald. 2001. Principles of Seed Science and Technology. 4th edition. Kluwer Academic Publishers. London. 425 p.

Delouche, J.C. 1971. Development of methods for predicting the longevity of ccrop seed lots in storage. Miss. State College. Coop. Agreement 12-14-100-9010 (51).

Dolatabadian, A. dan S.A.M Modarres Sanavy. 2008. Effect of the ascorbic acid, pyridoxine and hydrogen peroxide treatments on germination, catalase activity, protein, and malondialdehyde content of three oil seeds. Not. Bot. Hort. Agrobot. Cluj. 36: 61-66.

Halimursyadah dan E. Murniati. 2008. Pengaruh senyawa antioksidan sebelum simpan terhadap umur simpan benih kapas (Gossypium hirsutum L.). J. Floratek 3: 1-9.

Jannah, R. 2014. Pengaruh Periode Simpan dengan Menggunakan Asam Askorbat dari Ekstrak Buah Nanas terhadap Viabilitas dan Vigor pada Dua Varietas Benih Kedelai (Glycine max (L.) Merril.). Skripsi. Fakultas Pertanian Universitas Syiah Kuala. Banda Aceh.

Junita, D. 2014. Pengaruh Konsentrasi Ekstrak Kunyit dan Lama Inkubasi terhadap Viabilitas dan Vigor Benih Kedelai (Glycine $\max$ (L.) Merril.). Skripsi. Fakultas Pertanian Universitas Syiah Kuala. Banda Aceh.

Efektivitas Ekstrak Jambu Biji Merah (Psidium guajava L.) sebagai Antioksidan terhadap Laju Kemunduran Beberapa Varietas Benih Kedelai (Glycine max (L.) Merril.) (Dewi Muetia Tasfa, Syamsuddin, Halimursyadah) Jurnal Ilmiah Mahasiswa Pertanian Unsyiah, Vol. 1, No. 1, November 2016: 239-250 
Liming, S., D. M. Orecutt \& J,G Foster. 1992. Influence of PEG \& aeration methode during imbibition on germination \& subsequent seedling growth of flatpea (Lashyrus sylvestris). Seed Sci. \& Techn. $20: 349-357$.

Lumbanraja, S.S.O. 2006. Pengaruh Pemberian Antioksidan Sebelum Simpan terhadap Viabilitas dan Vigor Benih Pepaya (Carica papaya L.). Skripsi. Institut Pertanian Bogor. Bogor.

Marliah, A., T. Hidayat., N. Husna. 2012. Pengaruh varietas dan jarak tanaman terhadap pertumbuhan dan hasil tanaman kedelai (Glycine max L.). Universitas Syiah Kuala. Banda Aceh. J. Agrista. 16 (1): 22-28.

Marwoto, D.K.S. Swastika, dan P. Simatupang, 2005. Pengembangan kedelai dan kebijakan penelitian di Indonesia. Badan Litbang Pertanian. Jakarta. 19 p.

Purwanti, S. 2004. Kajian suhu ruang simpan terhadap kualitas benih kedelai hitam dan kedelai kuning. Ilmu Pertanian. Vol. 11 No. 1, 2004: 22-31 p.

Rachmawati, L. 2010. Isolasi, Identifikasi dan Uji Aktivitas Antioksidan Senyawa Flavonoid Daunbinahong (Anredera cordifolia (Ten.) Steenis). Fakultas Sains dan Matematika Universitas Diponegoro.

Riana, A. 2000. Jambu Biji. http://www.asiamaya.com/nutrients/jambubiji.html [diakses pada 10 Juni 2016]

Rini, D.S., Mustikoweni dan Surtiningsih. 2005. Respon perkecambahan benih sorgum (Sorgum bicolor (L.) Moerch.) terhadap perlakuan osmoconditioning dalam mengatasi cekaman salinitas. Jurnal Biologi. 7(6); 307-313 p.

Rizki, N. 2013. Pengaruh Taraf Kemunduran dan Potensial Osmotik Larutan $\mathrm{KNO}_{3}$ Terhadap Efektivitas Invigorasi Benih Kedelai. Skripsi. Fakultas Pertanian Universitas Syiah Kuala. Banda Aceh.

Sadjad, S. 1993. Kuantifikasi Metabolisme Benih. Gramedia, Jakarta.

Tatipata, A., P. Yudono, A. Purwantoro, dan W. Mangoendidjojo. 2004. Kajian Aspek Fisiologi dan Biokimia Deteriorasi Benih Kedelai dalam Penyimpanan. Ilmu Pertanian. 11(2): p.76-87.

Yuningsih, A.F.V. 2009. Pengaruh aplikasi Methylobacterium spp. terhadap viabilitas benih buncis (Phaseolus vulgaris L.) selama penyimpanan. Skripsi. Fakultas Pertanian. Institut Pertanian Bogor. Bogor. 